\title{
MERCURY AND ARSENIC CONTAMINATION FROM SMALL SCALE GOLD MINING ACTIVITIES AT SELOGIRI AREA, CENTRAL JAVA, INDONESIA
}

\author{
Agung Harijoko*1, Tin May Htun ${ }^{2}$, Rodhie Saputra ${ }^{1}$, I Wayan Warmada ${ }^{1}$, Lucas Donny \\ Setijadji ${ }^{1}$, Akira Imai ${ }^{3}$, and Koichiro Watanabe ${ }^{3}$ \\ ${ }^{1}$ Department of Geological Engineering, Gadjah Mada University, Indonesia \\ ${ }^{2}$ Department of Geology, Yangon University, Yangon, Myanmar \\ ${ }^{3}$ Department of Earth Resources Engineering, Kyushu University, Japan
}

\begin{abstract}
Small scale gold mines discussed here are located at Selogiri area, Central Java, Indonesia which was mined by local community mainly during gold rush in 1990s. This Selogiri gold deposit genetically is characterized by porphyry mineralization overprinted by epithermal system. The ore minerals assemblage consists of pyrite, sphalerite, chalcopyrite, galena, chalcocite and rare arsenopyrite.

Chemical analysis of soil and stream sediment sampled over $1.5 \mathrm{~km}$ across at the Selogiri gold extraction site indicates that the site has been contaminated with mercury due to mining activities. The mercury concentrations in soil and stream sediments collected during dry season range from 0.01 to $481 \mathrm{ppm}$ and 0.01 to $139 \mathrm{ppm}$, respectively, higher than background value of $0.05 \mathrm{ppm}$. In contrast, mercury concentration in stream sediments collected during rainy season from the same location as dry season sampling ranges from 0.01 to $13.42 \mathrm{ppm}$, and one sample has anomalous value of $331 \mathrm{ppm}$. This result show that rain water may disperse and decrease mercury concentration in stream sediments.

In case of arsenic, although the ore contains rare arsenic minerals, arsenic concentration in bulk rock and ore is high ranging from 8 to $59 \mathrm{ppm}$, while the arsenic concentration in tailing is much higher ranging from 5.8 to 385 ppm. Chemical analyses on pyrite reveal that the pyrite grains contain arsenic and might be the source of arsenic in Selogiri mine site. However, analysis of dug-well water demonstrates that the mercury and arsenic content is still lower than the maximum allowable concentration.
\end{abstract}

*Corresponding author: A. HARIJOKO, Department of Geological Engineering, Faculty of Engineering, Gadjah Mada University, Jl. Grafika 2 Yogyakarta, 55281, Indonesia. E-mail: aharijoko@ugm.ac.id
Keywords: mercury, arsenic, contamination, Selogiri, gold mine

\section{Introduction}

Indonesia, composed of several volcanic arcs ranging from Tertiary to Quaternary, have many potential gold deposits (Carlile \& Mitchell, 1994) such as Gunung Pongkor (e.g., Syafrizal et al., 2007; Warmada et al., 2003, 2007), Batu Hijau (Garwin, 2000; Idrus et al., 2007). Despite the occurrence of world class gold deposits there are many smaller deposits that is not interesting enough for mining companies. Therefore those deposits are still undeveloped. This condition has attracted local communities to operate small scale gold mines that are largely done without any consideration to the environment and mining safeties. In other words, this activity on the small scale gold mine which is commonly practiced in the developing countries is vulnerable to their safety as well as environmental quality.

One of the small scale gold mines in Indonesia was excavated in the Selogiri area, Central Java. Selogiri is one of the gold prospects in Indonesia, which has been mined since 1990s by the local community. It is located in Wonogiri Residency, southern part of Central Java, Indonesia (Figure 1). Gold mineralization in this area is a porphyry-type overprinted by low-sulphidation type epithermal system (Imai $e t$ al., 2007). JICA-JOGMEC (2004) estimated the gold reserve of this deposit about $206 \mathrm{~kg}$ of gold with the gold grade of about several tens to several hundreds $\mathrm{g} / \mathrm{t}$. However, analytical data shows average values less than $1 \mathrm{~g} / \mathrm{t}$ (only one sample is more than $1 \mathrm{~g} / \mathrm{t}$ ) (Setijadji et al., 2004). The gold has been mined using 
a complex adit and shaft entry method. Then, gold is recovered with amalgamation method similar to the method that is described by James (1994). The gold product of this small scale mine is about $10 \mathrm{~g}$ per day.

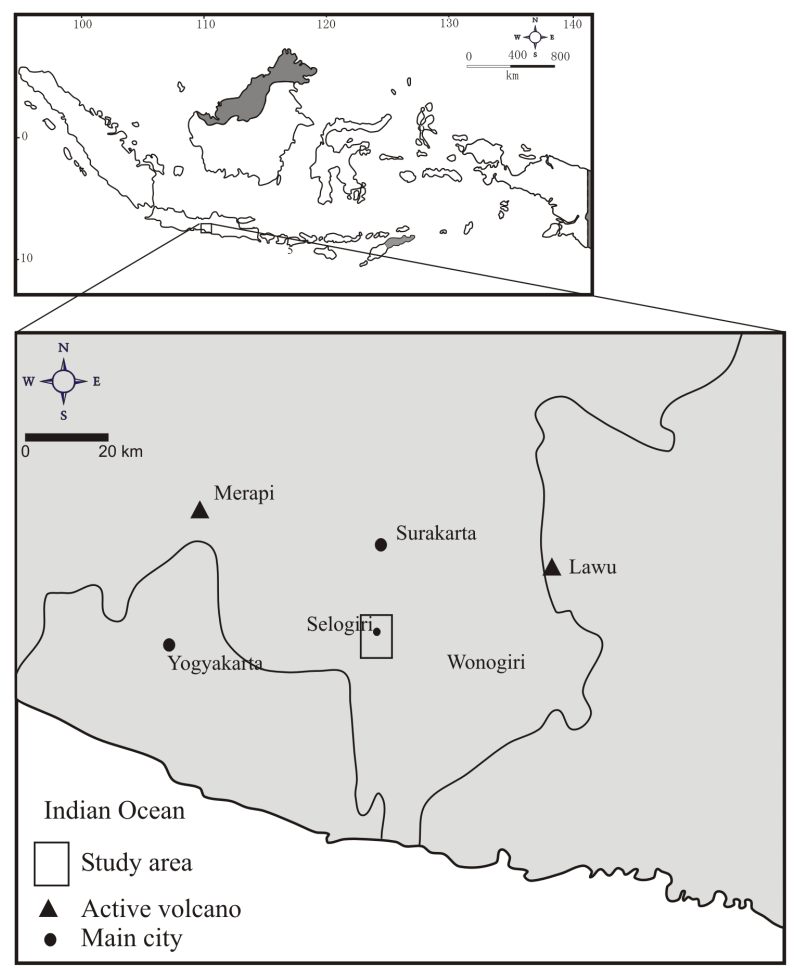

Figure 1: Location map of Selogiri area

Setijadji et al. (2004) estimated several hundred kilograms of mercury have been used to extract gold since early 1990s. The area over $1.5 \mathrm{~km}$ radius from the Selogiri gold extraction site is considered to be contaminated by mercury based on mercury concentration in soil and stream sediments. Moreover, other hazardous element such as arsenic potentially contaminates the same area.

In order to understand the concentration of contaminant elements, geochemical mapping of mercury and arsenic concentration in tailings, stream sediments, soils, river water and well water was conducted. In addition, the source of mercury and arsenic is also discussed on the basis of chemical analysis of ores and wall rocks. Mineralogical analysis was also conducted on ore and stream sediment samples in order to identify the minerals containing mercury and arsenic as well as their solid phases. We also collected samples during dry and rainy seasons in order to understand the effect of seasonal variation on the level of contamination in the study area.

\section{Geology and mineralization}

The detailed geologic setting of Selogiri was described in detail in previous papers (Prasetyanto et al., 1997; Soe et al., 2004; Widagdo and Pramumijoyo, 2004). The Selogiri area belongs to the western part of Southern Mountain range in Central Java, Southern Mountain consists of a series of mixed and flysh-like rocks with a total thickness of about 4500 m (Bothe, 1929; vide Rahardjo et al., 1993). These rocks unconformably overlie the Pre-Tertiary metamorphic rocks and Eocene sedimentary formation of the Jiwo Hill complex, which was covered by limestone formation (Gamping-Wungkal Formation). The series of mixed and flysh-like rocks can be divided into Oligocene-Lower Miocene of KeboButak Formation, Sambipitu Formation of EarlyMiddle Miocene age, and Oyo Formation of Middle Miocene age. These formations are unconformably overlain by Middle Miocene-Pliocene limestone of Wonosari Formation, Late Miocene of Kepek Formation, and Quaternary alluvial deposits.

The geological succession of the Southern Mountain in the Selogiri area consists of two Tertiary formations, i.e., sandstone of Kebo-Butak Formation and igneous rocks of Mandalika Formation (Surono et al., 1992). According to Toha et al. (1994), the sandstone unit is a member of Kebo-Butak Formation, whereas a breccia unit is a member of Besole Formation. Both Formations were intruded by Oligocene igneous rocks. Magmatism started at Late Oligocene with the intrusion of microdiorite (about 21.7 Ma [JICA-JOGMEC, 2004]) and the intrusion of Late Miocene-Pliocene diorite. The diorite is close to the $\mathrm{K}-\mathrm{Ar}$ date of hornblende-rich tuff of about $12.5 \pm$ $0.9 \mathrm{Ma}$ to $11.9 \pm 0.7 \mathrm{Ma}$ (Akmaluddin et al., 2005). The earlier intrusion was cut by a NW-SE dextralslip fault, and N-S and NE-SW sinistral-slip faults (Widagdo and Pramumijoyo, 2004).

There are four main type of rocks present in the Selogiri area (Figure 2) comprising volcanic (andesitic) breccia, tuffaceous sandstone, microdiorite, and diorite, covered by alluvial deposits. The Selogiri area consists of three different types of intermediate to silicic intrusive rocks, i.e., hornblende diorite porphyry, hornblende diorite, and hornblende andesite porphyry (Imai et al., 2007). Based on total alkali silica (TAS) diagram of the Le Bas et al. (1986), the rocks have a broad range definition, i.e., from basalt to dacite (Warmada et al., 2005). Geochemically, the rocks from Selogiri range from primitive to relatively differentiated compositions, as reflected by wide range of $\mathrm{SiO}_{2}, \mathrm{MgO}$ contents and variable concentrations of the mantle-compatible elements. High $\mathrm{La} / \mathrm{Yb}$ and $\mathrm{Zr} / \mathrm{Y}$ ratios (1.7-7.68 and 3.9513.75 , respectively) are characteristic of calc-alkaline 
rocks. These are confirmed by mantle-normalized trace element patterns, showing typical calc-alkaline island arc trace element patterns (Warmada et al., 2005).

Mineralization is characterized by quartz veinlet stockworks associated with magnetite and accompanied by malachite coating along cracks in the diorite porphyry. The mineralization represents an occurrence of porphyry-type deposit in Central Java. The existing small-scale mines are distributed along NS-trending quartz veins associated with base metal sulfides. The base metal mineralization is formed in an epithermal environment that overprinted the hydrothermal system of porphyry-type mineralization (Imai et al., 2007). Ore minerals associated with the Selogiri deposit include pyrite, sphalerite, chalcopyrite, galena, chalcocite and rare arsenopyrite identified using ore microscope (Soe et al., 2004). Host rock of the quartz veins is hydrothermally altered intrusive diorite and andesitic volcanic rocks (Soe et al., 2004).

\section{Samples and analytical methods}

Field investigation indicates that the small-scale miners disposed both the hydrothermally altered wall rocks and pulverized ore as tailings. Mercury and arsenic may occur either as aqueous phase dissolved in water or as solid phases in stream sediments. In this study, we conducted both chemical and mineralogical analyses of ore, wall rock and stream sediment samples and chemical analysis of mercury and arsenic in tailings, soils, river water, and well water. Sampling procedure of soil and water. Table 1 summarizes all samples and their types, while sample locations are depicted in Figure 3.

Metal minerals in ore. Ore microscopy observation was conducted to identify the metal-bearing minerals in the quartz vein that are often mined. Samples were collected from quartz vein outcrops. The samples are then analyzed for their chemical composition by an X-Ray Fluoresecene spectrometer (XRF) using Rigaku RIX 2100 at the Department of Earth Resources Engineering of Kyushu University. Chemical composition of minerals was analyzed by an electron probe microanalyzer (EPMA) JEOL JCMA 733 mkII at the Department of Earth and Planetary Sciences of University of Tokyo. The operating condition of these micro analyses were $25 \mathrm{kV}$ accelerating voltage and $20 \mathrm{nA}$ beam current, and computed by conventional ZAF calculation using factors and program supplied by JEOL.
Metal minerals in stream sediments. X-ray diffractometry (XRD) was utilized to identify the distribution and occurrence of metal-bearing minerals in the stream sediments. Eight samples of silt size particles were collected from the stream channels. Then, heavier metal-bearing minerals were separated from lighter stream sediment materials by panning. The samples were analyzed at the Department of Geological Engineering of Gadjah Mada University in Indonesia, by Multiflex series of Rigaku X-ray diffraction unit.

Arsenic concentration in tailings. Tailings are waste materials from the mining process. Fifteen tailings samples were collected from the amalgamation sites. The samples were first dried and then sieved. The materials retained in 100 meshes $(+150 \mu \mathrm{m})$ were used for analyses. The selected materials were then pulverized for determination of arsenic concentration using an inductively coupled plasma spectrometry (ICP-MS) in Activation Laboratories Ltd. Ontario, Canada.

Mercury concentration in soil and stream sediment. Soil and stream sediment samples were analyzed mainly to determine the concentration of mercury. Stream sediment samples were collected during the rainy season in order to know the seasonal variation of mercury concentration in sediments. During the rainy season, mine holes is normally flooded and the dewatering system is poor and limited, hence less mining activity during this season. Consequently, the build-up of tailings and the usage of mercury are lower during the rainy season than in the dry season.

Chemical analysis of water. In order to examine the possible effects of small-scale mining on drainage water composition, twenty water samples were collected in acid-washed polyethylene bottles during the rainy season. Water was collected from surface of rivers and from the wells in the area. Water $\mathrm{pH}$ was measured in the field using a portable $\mathrm{pH}$ meter. Water samples were filtered in the laboratory using a $0.45 \mu \mathrm{m}$ cellulose nitrate membrane filters (Sartorius, Germany). They were immediately acidified with 3-4 $\mathrm{ml}$ of concentrated nitric acid (Merck Suprapur) per liter of sample. Arsenic content was determined by graphite furnace atomic absorption spectrophotometer (AAS) in the National Atomic Agency of Indonesia (BATAN) in Yogyakarta.

Mercury content in the well water was also determined. Six well waters were analyzed using mercury analyzer SP-3 at the Department of Earth Resources Engineering, Kyushu University. 

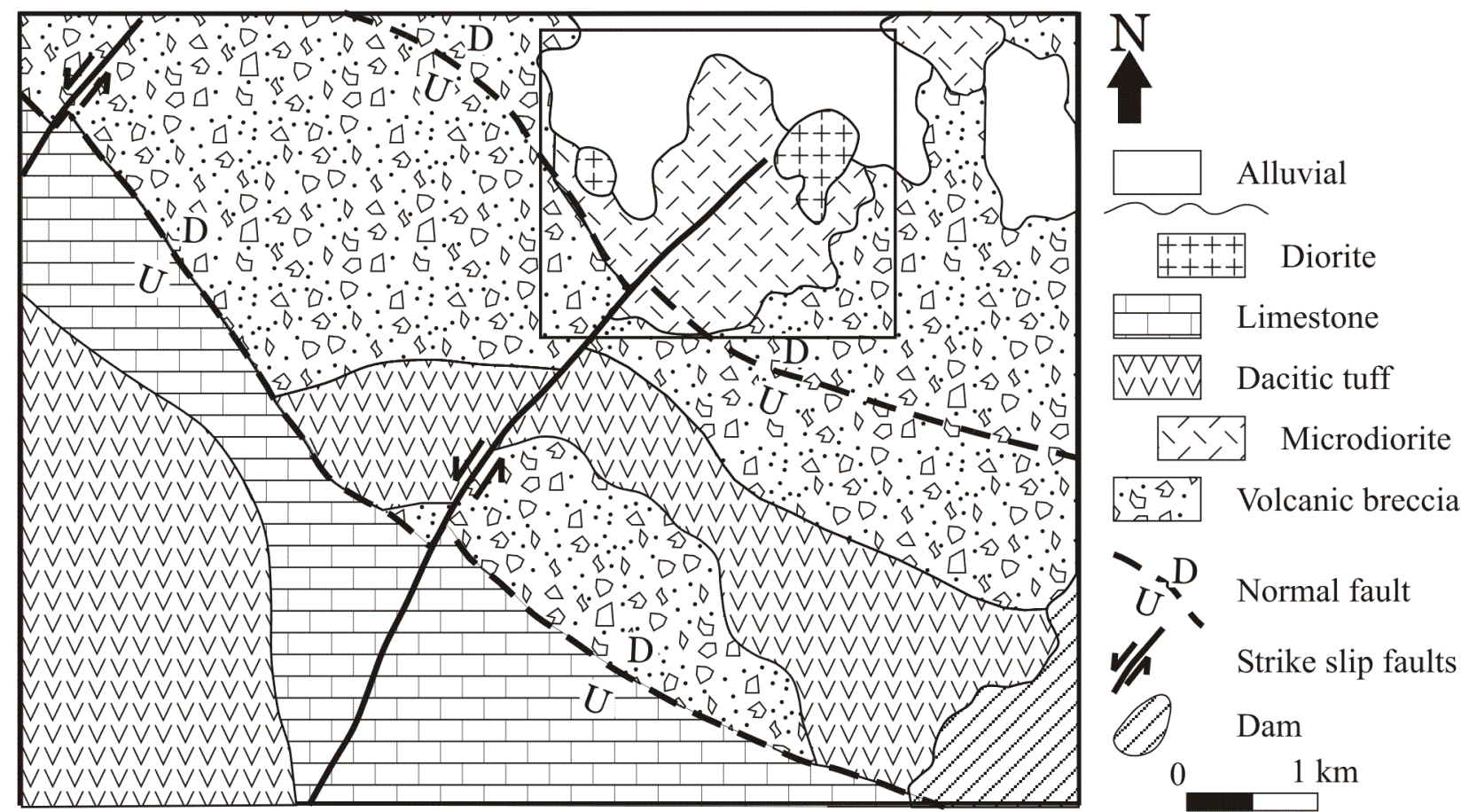

Figure 2: Geological map of Selogiri area and adjacent area

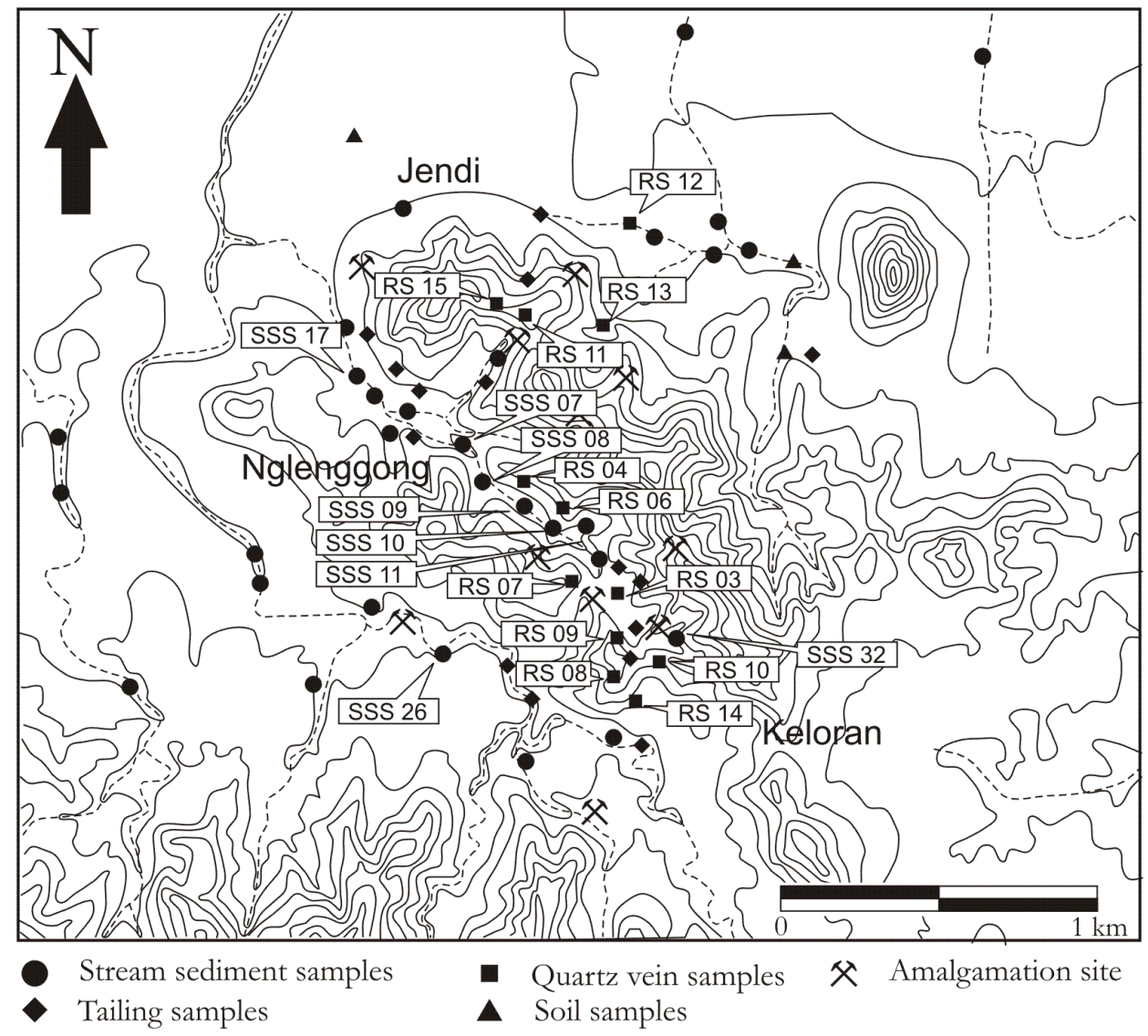

Figure 3: Map of sample locations collected in this study 


\section{Results and discussions}

\subsection{Metal minerals content in ores and stream sediments}

Natural source of toxic elements is largely from metal minerals in ore deposits. The release of toxic elements to the environment may however, be induced by human activities such as mining. Therefore, in order to understand the source of mercury and arsenic in the study area, the content of metal minerals in ores was studied. Metal minerals content in the stream sediments are also worthy to be identified since they can be transported and become the source of toxic elements.

As reported by Imai et al. (2007), the ore deposit at Selogiri is a porphyry type overprinted by lowsulphidation type epithermal system. Those systems commonly contain some amount of arsenic minerals such as arsenopyrite and minor mercury minerals such as cinnabar (Hedenquist et al., 1996; Palacios et al., 1992). However, previous studies on ore minerals (i.e., Soe et al., 2004; Imai et al., 2007) did not report the presence of mercury minerals. Rare arsenic minerals were identified.

In this study we observed under the microscope on 12 ore samples and the identified metal minerals include sphalerite, galena, pyrite and chalcopyrite. Some photomicrographs of the metal minerals are shown in Figure 4. XRD analysis of eight stream sediment samples shows that metal minerals assemblage consists dominantly of pyrite and magnetite and minor chamosite, manganite, pyrolusite and hematite. No mercury and arsenic minerals were identified in ore and stream sediments samples. However chemical analyses show that tailings and stream sediments contain some amount of mercury and arsenic of 11.8-790 ppm and 5.8-385 ppm respectively (Table 1). Since arsenic is not added during small scale mining and processing it should be occurring naturally in ores. In case of mercury it can be natural or be added due to gold extraction process.

\subsection{Mercury concentration and distribution}

The amount of mercury in rocks may occur naturally or anthropogenically (induced by human activities). Natural mercury enrichment may be caused by hydrothermal fluids associated with gold mineralization, while one of anthropogenic process is human activities in gold extraction from the ores. In this study, the background value of mercury content is that of fresh diorite $(0.01 \mathrm{ppm})$. Therefore, we determined the mercury concentration of hydrothermaly altered diorite and of tailing to know the most prominent factor in mercury enrichment in the study area. Then, in order to measure the degree of contamination, mercury contents of soil and dug-well water were analyzed. Stream sediments as a potential distribution agent were also analyzed.

Setiadji et al. (2004), who carried out the surveys during dry season, reported the mercury content of the fresh diorite collected from the Selogiri area is $0.01 \mathrm{ppm}$. The mercury content of the hydrothermally altered diorite is $2.58 \mathrm{ppm}$ and those of waste dump materials range from 0.1 to $0.9 \mathrm{ppm}$. This indicates that mercury is enriched naturally due to mineralization about two orders of magnitude. In contrast, the mercury content of tailings ranges from 11.8 to $790 \mathrm{ppm}$. The enrichment is about four orders of magnitude. These results indicate that natural mercury enrichment due to hydrothermal activity is lower than mercury enrichment due to gold extraction by amalgamation method.

Setidjaji et al. (2004) reported that mercury contamination occurs at the Selogiri area up to $1.5 \mathrm{~km}$ across from amalgamation site. This is based on a threshold value of $0.05 \mathrm{ppm}$ in soil, and a background value of $0.01 \mathrm{ppm}$. Mercury contents of 84 soil samples collected during the dry season range from less than $0.01 \mathrm{ppm}$ to $481 \mathrm{ppm}$, whereas mercury concentration of stream water is up to $0.5 \mathrm{ppm}$. The stream sediment samples contain mercury ranging from less than 0.01 to $139 \mathrm{ppm}$ (Table 1). Small scale gold mining is the main cause of mercury contamination in Selogiri.

In order to determine the effect of rainfall on the mercury content during different seasons, mercury contents of stream sediment samples collected during the rainy season were also analyzed. Samples of stream sediments were collected in the same locations as during an earlier dry season (Setijadji et al., 2004). Results show that the mercury content of the stream sediments during rainy season ranges from 0.01 to 313 ppm (Table 1 ). Figure 5 shows the correlation between mercury concentration in stream sediments during dry and rainy season. The correlation is positive. More rain water generally decreases mercury concentration in stream sediments by up to $40 \%$. Mercury will transport further downstream during the rainy season enlarging contaminated area.

\subsection{Arsenic concentrations, distribution and source}

Arsenic is a common element associated with gold mineralization that is often used as a path finder element during gold exploration. Arsenic also commonly occurs in epithermal gold deposits as arsenopyrite and arsenian pyrite implying that the 

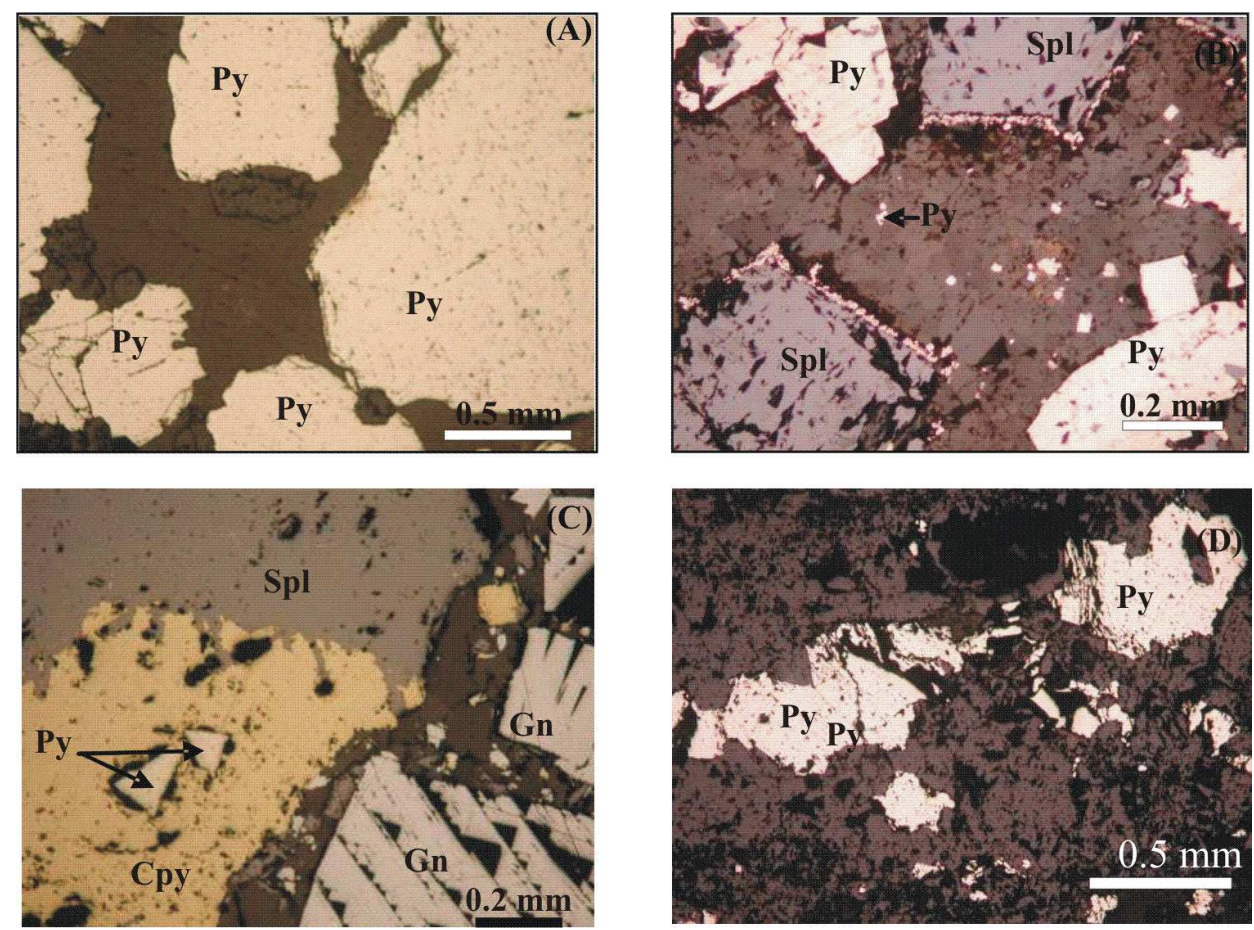

Figure 4: Photomicrographs of identified metal mineral in ore (A) sample RS 10, (B) sample RS 12, (C) sample RS 14 and (D) sample RS 06. Dominant metal minerals are pyrite (py), sphalerite (Spl), galena (Gn), chalcopyrite (Cpy)

Table 1: Mercury and arsenic concentration in samples from Selogiri

\begin{tabular}{lcc}
\hline Sample types & $\begin{array}{l}\text { Hg concentration } \\
(\mathbf{p p m})\end{array}$ & $\begin{array}{l}\text { As concentration } \\
\text { (ppm) }\end{array}$ \\
\hline Tailing & $11.8-790^{*}$ & $5.8-385$ \\
\hline Soil during rainy season & $0.01-3.63$ & - \\
\hline $\begin{array}{l}\text { Stream sediment during } \\
\text { rainy season }\end{array}$ & $0.01-13.42$ & - \\
\hline Fresh diorite* & 0.01 & - \\
\hline $\begin{array}{l}\text { Hydrothermally altered } \\
\text { diorite* }\end{array}$ & 2.58 & $8-59$ \\
\hline Soil during dry season* & $0.01-481$ & - \\
\hline $\begin{array}{l}\text { Stream sediment during } \\
\text { dry season* }\end{array}$ & $0.01-139$ & - \\
\hline
\end{tabular}

*) from Setijadji et al. (2004) 


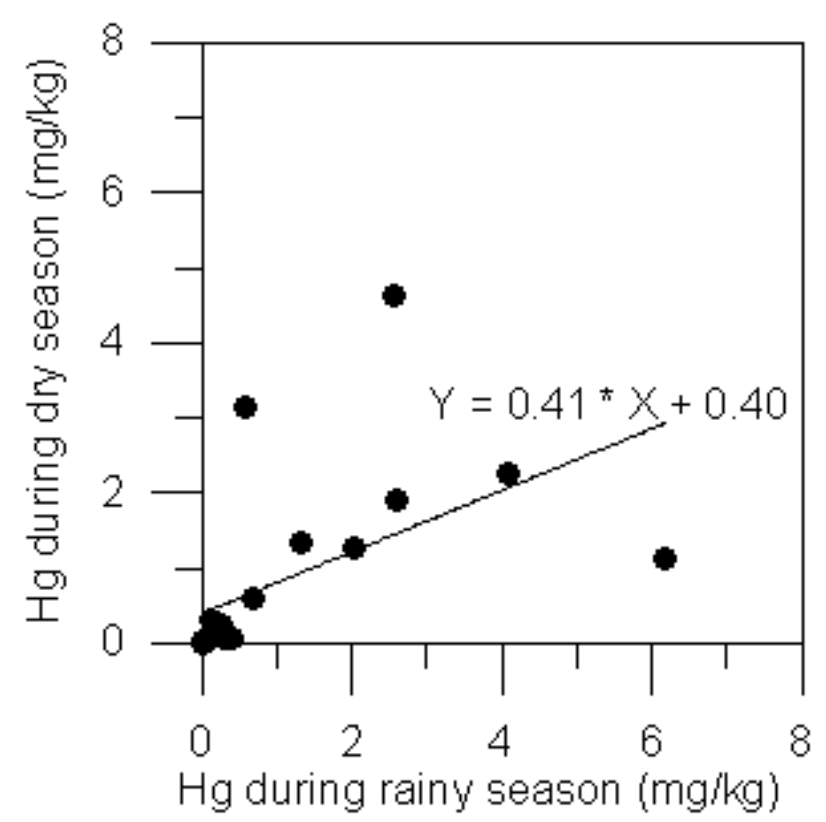

Figure 5: Relationship between mercury concentration of the stream sediments during dry season and rainy season

area surrounding gold mineralization is prone to arsenic contamination.

The natural arsenic contents of host rocks and ores in the Selogiri area are known from bulk-rock and bulk-ore geochemical analyses. The result shows that the host rocks (mainly andesite) contain arsenic in a range from 8 to $59 \mathrm{ppm}$. Soe (2005) reported three ore samples with arsenic concentration up to $873 \mathrm{ppm}$. The arsenic contents of the 15 tailing materials from the amalgamation units range from 5 to 385 ppm.

Since no arsenic is added during small scale gold mining and processing, the source of arsenic in tailings, soils and steam sediments is metal minerals in the Selogiri deposit. The arsenic contents of the ore range from $49 \mathrm{ppm}$ to $1888 \mathrm{ppm}$ (Table 2). The back scattered electron image of pyrite grain in sample RS-06 shows that pyrite has compositional zoning (Figure 6). The arsenic content of the pyrite grains varies from 0.18 to $0.53 \mathrm{wt}$. $\%$ (Table 3). There is no regular systematic arsenic concentration in the pyrite grains is found. This result reveals that some pyrites in ores of the Selogiri area are arsenian pyrite and may be the source of arsenic contamination.

\section{Conclusions}

Based on the results of the analyses conducted in this study, we conclude that small scale gold mining is a potential source of hazardous elements such as mercury and arsenic. The concentration of mercury in
Table 3: Chemical composition of pyrite in RS-06 (in wt $\%)$

\begin{tabular}{cccc}
\hline Position & Fe & S & As \\
\hline 1 & 46.641 & 53.599 & bdl \\
2 & 46.176 & 53.068 & 0.286 \\
3 & 47.307 & 53.560 & 0.360 \\
4 & 46.426 & 53.506 & 0.182 \\
5 & 46.783 & 53.655 & bdl \\
6 & 46.472 & 53.666 & 0.531 \\
7 & 46.197 & 53.107 & 0.408 \\
8 & 46.201 & 54.197 & $b d l$ \\
9 & 47.142 & 54.091 & $b d l$ \\
10 & 46.843 & 53.799 & $b d l$ \\
11 & 46.609 & 53.883 & 0.488 \\
12 & 46.170 & 54.503 & $b d l$ \\
\hline
\end{tabular}

Note: $b d l=$ below detection limit

stream sediments is highly influenced by water dispersion.

The arsenic contents of tailing materials range from 5 to 385 ppm, even though the arsenic mineral is rare. Pyrite at the Selogiri deposit contains some amounts of arsenic. Such arsenian pyrite is a likely source of arsenic in the Selogiri area.

\section{Acknowledgement}

The authors thank to JICA for the research grant through AUN Seed-Net Collaborative Research on Integrated Study on Earth Resources within the Island Arc and Continental Margin Geological Setting of South East Asia. We thank Mr. H. Yoshida of Department Earth and Planetary Sciences of the University of Tokyo for electron probe microanalysis of pyrite. We extend our gratitude to the Resource Geology reviewer for their constructive review.

\section{References}

Akmaluddin, Setijadji, L. D., Watanabe, K. and Itaya, T. (2005) New interpretation on magmatic belts evolution during the Neogene-Quaternary periods as revealed from newly collected K-Ar ages from Central-East Java - Indonesia. Proceedings Joint Convention Surabaya 2005 - HAGI-IAGI-PERHAPI, 235-238.

Idrus, A., Kolb, J. and Meyer, M (2007) Chemical Composition of Rock-Forming Minerals in Copper-Gold- 
MERCURY AND ARSENIC CONTAMINATION AT SELOGIRI AREA

Table 2: Trace elements concentration in ores from Selogiri (in ppm)

\begin{tabular}{crrrrrr}
\hline $\begin{array}{c}\text { Trace } \\
\text { Elements }\end{array}$ & RS-03 & RS-06 & RS-07 & RS-08 & RS-10 & RS-11 \\
\hline $\mathrm{Ag}$ & 60 & 68 & 16 & 46 & 71 & 71 \\
$\mathrm{Cu}$ & 61 & 2 & 16 & bdl & 310 & 68 \\
$\mathrm{Cd}$ & 88 & 31 & 21 & 4 & 26 & 57 \\
$\mathrm{As}$ & 49 & 1888 & 97 & 69 & 667 & 832 \\
$\mathrm{Sr}$ & 25 & 22 & 13 & 12 & 16 & 22 \\
$\mathrm{Hg}$ & 15 & 3 & $b d l$ & 18 & $b d l$ & 22 \\
$\mathrm{~Pb}$ & 36 & 103 & 13 & 16 & $b d l$ & 3 \\
\hline
\end{tabular}

Note: $b d l=$ below detection limit
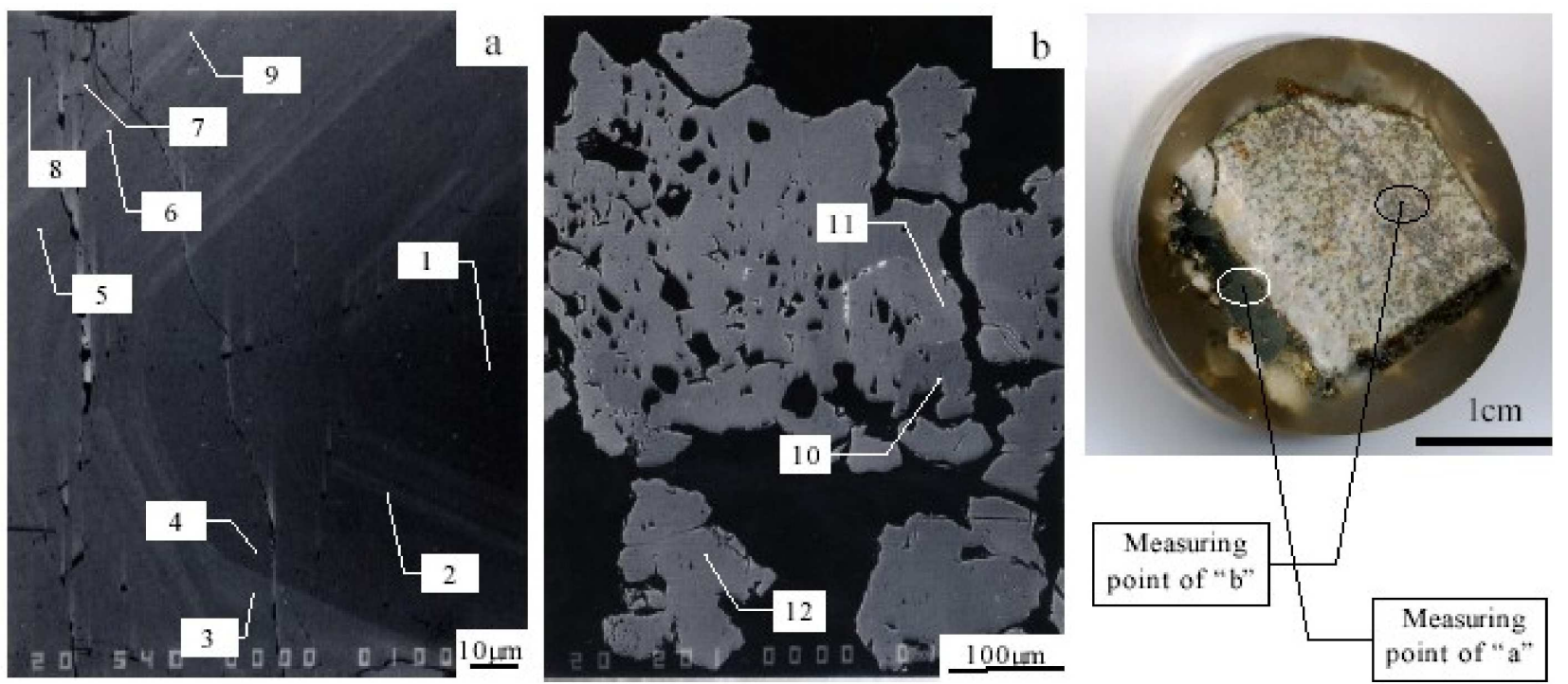

Figure 6: Back scattered electron image of pyrite (RS-06) showing zoning of pyrite and the spot analyzed by electron probe microanalyzer 
Bearing Tonalite Porphyries at the Batu Hijau Deposit, Sumbawa Island, Indonesia: Implications for Crystallization Conditions and Fluorine-Chlorine Fugacity. Resource Geol. 57, 102 - 113.

Imai, A., Shinomiya, J., Soe, M. T., Setijadji, L. D., Watanabe, K., Yoshikawa, R. and Warmada, I W. (2007) Porphyry-type mineralization at Selogiri area, Wonogiri regency, Central Java, Indonesia. Resource Geol. 57, 135-140.

JICA-JOGMEC, (2004), Report on the Mineral Exploration in the East Java Area, the Republic of Indonesia Consolidated Report, the Japan International Cooperation Agency and the Japan Oil, Gas and Metals National.Corporation, Tokyo.

Palacios, M. C., Lahsen, A. A. and Sylvester, H. (1992) Low-sulfur epithermal gold mineralization at Inca de Oro, northern Chile: Mineralogy and fluid inclusions. Journal of South American Earth Sciences. 6, 183-189.

Prasetyanto, I. W., Widodo and Wintolo, D. (1997) Gold mineralization in Selogiri-Wonogiri, Central Java (in Indonesia). Proceedings of 17th Indonesian Association of Geologist Annual Conference, Jakarta.

Rahardjo, W., Sukandarrumidi and Rosidi, H. M. D. (1995) Geological Map of Yogyakarta Quadrangle, Scale 1:100.000. Pusat Penelitian dan Pengembangan Geologi, Bandung, (in Indonesian).

Setijadji, L. D., Tsuchiya, K., Harijoko, A., Unoki, R., Itoi, R. and Watanabe, K. (2004) Mercury contamination from small-scale mining in Selogiri area, Central Java, Indonesia: Evidence from $\mathrm{Hg}$ concentraqtion and spatial distribution in rocks, soil and stream sediment. Proceedings of the 1st International Symposium on Earth Resources Engineering and Geological Engineering Education, Yogyakarta, Indonesia 14 Dec. 2004, 20-24.
Soe, M. T. (2005) Geology and Gold-Copper Mineraization at Selogiri Area, Wonogiri Regency, Central Java, Indonesia, Gadjah Mada University, Yogyakarta, Indonesia, Master Thesis, Gadjah Mada University, Unpublished, 207p.

Soe, U. T., Sinomiya, J., Warmada, I W., Setijadji, L. D., Imai, A. and Watanabe, K. (2004) Geology and goldcopper mineralization at Selogiri area, Wonogiri regency, Central Java, Indonesia. Proceedings of the 1st International Symposium on Earth Resources Engineering and Geological Engineering Education, Yogyakarta, Indonesia 14 Dec. 2004, 20-24.

Surono, Toha, B., Sudarno, I. and Wiryosujono (1992) Geological Map of the Surakarta- Giritontro quadrangles, Java. PPPG Bandung, Scale 1:100,000.

Syafrizal et al 2007

Toha, B., Resiwati, P., Sriyono, Soetoto, Rahardjo, W. and Pramumijoyo, S. (1994) Geology of Southern Mountain: A contribution (in Indonesia). In: Proceedings of geology and geotectonic of Java Island from Late Mesozoic - Quaternary, Teknik Geologi-UGM, Yogyakarta, 19-36.

Warmada, I. W., Soe, M. T., Sinomiya, J., Setijadji, L. D., Imai, A. and Watanabe, K. (2005) Petrology and geochemistry of intrusive rocks from Selogiri area, Central Java, Indonesia. Proceedings of the 2nd International Symposium on Earth Resources Engineering and Geological Engineering Education. Bangkok, Dec. 2005, 163-169.

Widagdo, A. and Pramumijoyo, S. (2004) Tectonic phases of structural forming and its relationship with mineralization in Selogiri area, Wonigiri, Central Java. Proceedings of the 1st International Symposium on Earth Resources Engineering and Geological Engineering Education, Yogyakarta, Indonesia 14 Dec. 2004, 25-28. 